(REVIEW ARTICLE)

\title{
Importance of leptospirosis for human and animal health, present condition, problems and solution proposals in Turkey and the World
}

\author{
Bilgili Ali ${ }^{*}{ }^{*}$ and Hanedan Başak ${ }^{2}$ \\ 1 University of Ankara, Faculty of Veterinary Medicine, Department of Pharmacology and Toxicology, Ankara, Turkey. \\ 2 University of Ataturk, Faculty of Veterinary Medicine, Department of Internal Medicine, Erzurum, Turkey.
}

Publication history: Received on 07 November 2019; revised on 03 December 2019; accepted on 04 December 2019

Article DOI: https://doi.org/10.30574/wjarr.2019.4.2.0084

\begin{abstract}
Considering the fact that a major part of emerging diseases in humans are caused by animals and that animal health directly affects human health and animal products are undisputedly necessary in human nutrition, it is concluded that human health depends on animal health. Leptospirosis, commonly present in many domestic and wild animals in the world, caused by more than 250 pathogenic serotypes, is an important zoonotic bacterial disease that causes economic losses of breeders, negatively affects sustainable livestock production, and threatens public health. Human leptospirosis is acquired by contact with environmental sources such as water or soil, directly or indirectly contact with infected animals such as wild, livestock or pet animals, or occupational exposure. For this reason, prevention of infection in humans and its control depends on breaking of this contact chain and control of infection in animal reservoirs and its elimination. In this presentation context, with the specified reasons, concise knowledge was given on problems, actions to be taken, and solution proposals for prevention of leptospirosis, by tabularizing leptospirosis data in humans and animals in the recent years related to our country and border countries, including European countries, and the world countries.
\end{abstract}

Keywords: Leptospirosis; Human and animal health; Problems; Solution proposals

\section{Introduction}

Leptospirosis is a common zoonotic disease in many domestic and wild animals in the world [1]. Leptospirosis is caused by infection due to spirochete bacterium of the genus of Leptospira with over 250 pathogenic serovars [2]. Leptospirosis commonly occurs in tropical and subtropical areas [3]. Pathogenic leptospires remain alive in the environmental conditions but not propagate [3], not live in frozen environments, and die over $50 \stackrel{\circ}{ } \mathrm{C}$ [4]. The Leptospira bacteria are transmitted to humans with contact to infected environmental sources (e.g., water and soil), infected wild or domesticated animals or occupational exposure [5].

\section{Present condition}

Leptospirosis is the most common occupational disease occurring due to fresh water or animal exposure in temperate regions. Butchers, hunters, sewage and farm workers, veterinary surgeons, laboratory staff are mostly exposed to leptospirosis [6, 7]. Leptospirosis is considered environmental disease due to spare time activities such as canoe, rafting, canyon, hiking and other outdoor sports $[8,9]$. There are increased incidences for leptospirosis in humans who return travel [10]. Kutsuna et al. [11] have reported the leptospirosis occurrence in five cases who returned trip from Southeast Asia countries due to fresh water exposure.

\footnotetext{
${ }^{*}$ Corresponding author

E-mail address: abilgili61@gmail.com
} 
Leptospirosis epidemics generally occur due to water flooding in the events of heavy precipitation or hurricane, typhoon or earthquakes $[12,13]$. Leptospirosis cases have been reported in the result of water flooding after excessive rainfall in Nicaragua [14] and Philippines [15]. Seasonal peaks with high incidence of leptospirosis occur in Thailand [16] and tropical islands [17].

Important environmental factors associated with leptospirosis such as still waters, floods, poor canalization systems, and poor house cleaning have been reported in scientific articles published in Indonesia [18]. Other risk factors for leptospirosis are dirty surface, closeness to sewage systems, inattention to hygiene, walking barefoot, open wound, and gathering firewood [19].

Rodents, marsupials and mammals may be carrier and contaminate environment [20]. Important risk factors in dogs in North California are exposure to wild animals, living in farming areas, water exposure such as pond, stream, and pool [21].

Leptospires shed in urine of animals may live for months in warm and humid environment. Animals are mostly infected by environmental exposure. In some mammal species venereal transmission may occur. Transmission from person to person is rare [22]. Placental transmission may occur [4].

Humans generally are incidental host and infection occurs by exposure to urine of infected animals or exposure to contaminated water and soil $[3,23]$. Milking, abort materials, consumption of raw milk, slaughtering, and carrying animal carcass are also contamination sources. Laboratory animals are natural carriers. Thus, laboratory animals may be a contamination source for staff responsible from laboratory animals [24]. Hosts may spread bacteria via urine for months or lifelong [25]. Transmission may be via mouth, mucous membranes, and impaired skin integrity [26].

\subsection{Epidemiology}

The prevalence of leptospirosis in humans and animals in Turkey and in the world is presented in tables below.

Table 1 The human and animal cases due to leptospirosis identified by Etlik Veterinary Control Central Research Institution in 2017 (Ministry of Agriculture and Forestry, 2018) [27].

\begin{tabular}{llllllll}
\hline \multirow{2}{*}{ Province } & $\begin{array}{l}\text { Sample } \\
\text { Number }\end{array}$ & Human & \multicolumn{5}{l}{ Sheep } \\
\cline { 3 - 7 } Ankara & 92 & Total & Positive & Negative & Total & Positive & Negative \\
\cline { 2 - 7 } Bartın & 1 & 0 & 4 & 23 & 46 & 2 & 44 \\
Bolu & 1 & 1 & 0 & 0 & 0 & 0 & 0 \\
Çankırı & 1 & 0 & 0 & 0 & 0 & 0 & 0 \\
Çorum & 10 & 1 & 0 & 1 & 9 & 0 & 9 \\
Eskişehir & 18 & 0 & 0 & 0 & 15 & 0 & 15 \\
Karabük & 1 & 1 & 0 & 1 & 0 & 0 & 0 \\
Kayseri & 10 & 0 & 0 & 0 & 4 & 0 & 4 \\
Kırıkkale & 36 & 0 & 0 & 0 & 35 & 0 & 35 \\
Kırşehir & 22 & 0 & 0 & 0 & 22 & 0 & 22 \\
Kastamonu & 0 & 0 & 0 & 0 & 0 & 0 & 0 \\
Nevşehir & 0 & 0 & 0 & 0 & 0 & 0 & 0 \\
Yozgat & 14 & 0 & 0 & 0 & 6 & 0 & 6 \\
Zonguldak & 63 & 9 & 4 & 5 & 54 & 0 & 54 \\
Total & 269 & 39 & 8 & 31 & 191 & 2 & 18 \\
\hline
\end{tabular}


Table 2 The sheep and goat cases due to leptospirosis identified by Etlik Veterinary Control Central Research Institution in 2016 (Ministry of Agriculture and Forestry, 2018) [27].

\begin{tabular}{llll}
\hline & Total & Sheep & Goat \\
\hline Sample Number & 662 & 652 & 10 \\
Positive & 71 & 71 & \\
Negative & 591 & 581 & 10 \\
\hline
\end{tabular}

Leptospirosis was determined in 4 humans in the city of Ankara and Zonguldak, and in 2 sheep in the city of Ankara by Etlik Veterinary Control Central Research Institution in 2017.

Table 3 The leptospirosis in sheep according to importing country and province that animals are transported in 2016 (Ministry of Agriculture and Forestry, 2018) [27].

\begin{tabular}{lll}
\hline Province & Sheep & \\
\hline & Positive & Importing Country \\
Ankara & 23 & Ukraine \\
Balıkesir & 48 & Bulgaria \\
Total & 71 & \\
\hline
\end{tabular}

Leptospirosis was determined in sheep imported from Ukraine and Bulgaria to Turkey in 2016.

Table 4 Leptospirosis prevalence of animals in Turkey.

\begin{tabular}{lllll}
\hline Province & Animal & $\begin{array}{l}\text { Sample } \\
\text { Number }\end{array}$ & Prevalence (\%) & Scientific Source \\
\hline Kırşehir & $\begin{array}{l}\text { Microtus } \\
\text { hartingi }\end{array}$ & 43 & 46.5 & Azkur et al., 2013 [28] \\
Ankara & Stray dogs & 51 & 43.96 & Aslantaş et al., 2005 [29] \\
Various cities & Cattle & 15.596 & 8.04 & Özdemir and Erol, 2002 [30] \\
Kayseri & Cattle & 2395 & 25.42 & Gumussoy et al., 2006 [31] \\
Southern Marmara & Cattle & 922 & 3.4 & Kocabiylk and Çetin, 2004 [32] \\
Diyarbakır & Cattle & 96 & 9 & Yesilmen et al., 2012 [33] \\
Hatay & Cattle & 512 & 8.8 & Aslantaş and Özdemir, 2005 [34] \\
Afyon & Water & 93 & 32.26 & Kenar and Ozdemir, 2013 [35] \\
& Buffalo & & & \\
Kars & Cattle & 163 & 40.5 & Genç et al., 2005 [36] \\
Erzurum and Van & Sheep & 108 & 17 & Sağlam et al., 2008 [37] \\
\hline
\end{tabular}


Table 5 Leptospirosis prevalence of animals in the world.

\begin{tabular}{|c|c|c|c|c|}
\hline Country & Animal & $\begin{array}{l}\text { Sample } \\
\text { Number }\end{array}$ & Prevalence (\%) & Scientific Source \\
\hline Egypt & Rat & 270 & 75.9 & Samir et al., 2015 [38] \\
\hline Brazil & Rat & 47 & 36.2 & Lilenbaum et al., 1993 [39] \\
\hline Europe & Rat & 420 & 14.3 & Heuser et al., 2017 [40] \\
\hline Brazil & Capybara & 41 & 43.9 & de Alquerque et al., 2017 [41] \\
\hline France & Coypus & 133 & 76 & Vein et al. 2014 [42] \\
\hline Tanzania & Bat & 36 & 19.4 & Mgode et al., 2014 [43] \\
\hline Mexico & Crocodile & 48 & 100 & Perez-Flores et al., 2017 [44] \\
\hline Slovenia & Reptile & 297 & 25.0 & Lindtner-Knific et al., 2013 [45] \\
\hline Iran & Dog & 150 & 22 & Zakeri et al., 2010 [46] \\
\hline Spain & Dog & 338 & 25.8 & Lopez et al., 2019 [47] \\
\hline \multirow[t]{2}{*}{ Brazil } & Dog & 192 & 9.90 & Abreu et al., 2019 [48] \\
\hline & Rodent & 132 & 1.51 & \\
\hline Egypt & Dog & 168 & 58.3 & Samir et al., 2015 [38] \\
\hline Brazil & Feral cat & 57 & 2 & Ullmann et al., 2012 [49] \\
\hline Egypt & Cattle & 625 & 37.6 & Samir et al., 2015 [38] \\
\hline \multirow[t]{2}{*}{ India } & Cattle & 320 & 67.18 & Alamuri et al., 2019 [50] \\
\hline & Buffalo & 106 & 70.08 & \\
\hline India & Cattle & 267 & 75.66 & Govindan et al., 2015 [51] \\
\hline Sri Lanka & Cattle & 164 & 12.2 & Gamage et al., 2014 [52] \\
\hline Iran & Sheep & 75 & 17.33 & Zakeri et al., 2010 [46] \\
\hline Egypt & Sheep & 99 & 45.5 & Samir et al., 2015 [38] \\
\hline Brazil & Sheep & 308 & 47.4 & Martins et al., 2012 [53] \\
\hline New Zealand & Sheep & 399 & 57 & Fang et al., 2015 [54] \\
\hline \multirow[t]{2}{*}{ Chile } & Work Horse & 160 & 30.63 & Tadich et al., 2016 [55] \\
\hline & Military Horse & 266 & 23.31 & \\
\hline Pakistan & Horse & 384 & 33.85 & Sohail et al., 2016 [1] \\
\hline
\end{tabular}

Rodents were determined to be an important as leptospirosis resource in Turkey and the other countries (Tables 4 and 5).

Table 6 Leptospirosis prevalence of humans in Turkey.

\begin{tabular}{llll}
\hline Province & Sample Number & Prevalence (Number) & Scientific Source \\
\hline Samsun & 157 & 116 & Yllmaz et al., 2015 [56] \\
İstanbul & 35 & 22 & Turhan et al., 2006 [57] \\
Rize & 561 & 14 & Bilir, 2016 [58] \\
\hline
\end{tabular}


Table 7 Leptospirosis prevalence of humans in the world.

\begin{tabular}{llll}
\hline Country & Sample Number & Prevalence (\%) & Scientific Source \\
\hline Denmark & & $\begin{array}{l}0.34 / \text { per 100.000 } \\
\text { population }\end{array}$ & van Alphen et al., 2015 [59] \\
& & 28.6 & Mohd Ridzuan et al., 2016 [60] \\
Malaysia & 350 & 17.6 & Padma Kumari et al., 2016 [61] \\
India & 1209 & 13.4 & Cook et al., 2017 [62] \\
Kenya & 737 & 26.5 & Zakeri et al., 2010 [46] \\
Iran & 369 & 4.2 & Brockmann et al., 2016 [8] \\
Germany & 142 & 49.7 & Samir et al., 2015 [38] \\
Egypt & 175 & &
\end{tabular}

Table 8 Confirmed leptospirosis cases: number and rate/per 100.000 population in 2010-2014 in EU/EEA (ECDC, 2016) [63].

\begin{tabular}{|c|c|c|c|c|c|c|c|c|c|c|c|}
\hline \multirow[t]{2}{*}{ Country } & \multicolumn{2}{|l|}{2010} & \multicolumn{2}{|l|}{2011} & \multicolumn{2}{|l|}{2012} & \multicolumn{2}{|l|}{2013} & \multicolumn{3}{|l|}{2014} \\
\hline & Case & Rate & Case & Rate & Case & Rate & Case & Rate & $\begin{array}{l}\text { Reported } \\
\text { Cases }\end{array}$ & $\begin{array}{l}\text { Confirmed } \\
\text { Cases }\end{array}$ & Rate \\
\hline Austria & 9 & 0.1 & 3 & 0.0 & 16 & 0.2 & 15 & 0.2 & 9 & 9 & 0.1 \\
\hline Belgium & 7 & 0.1 & 15 & 0.1 & 16 & 0.1 & 15 & 0.1 & 34 & 34 & 0.3 \\
\hline Bulgaria & 11 & 0.1 & 12 & 0.2 & 4 & 0.1 & 3 & 0.0 & 43 & 31 & 0.4 \\
\hline Croatia & . & . & . & 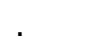 & . & . & 0 & 0.0 & 105 & 105 & 2.5 \\
\hline Cyprus & 0 & 0.0 & 0.0 & 0.0 & 0.0 & 0.0 & 0.0 & 0.0 & 0 & 0 & 0.0 \\
\hline Czech & 40 & 0.4 & 31 & 0.3 & 22 & 0.2 & 6 & 0.1 & 37 & 35 & 0.3 \\
\hline \multicolumn{12}{|l|}{ Republic } \\
\hline Denmark & 6 & 0.1 & 9 & 0.2 & 7 & 0.1 & 3 & 0.1 & 7 & 7 & 0.1 \\
\hline Estonia & 1 & 0.1 & 2 & 0.2 & 5 & 0.4 & 2 & 0.2 & 2 & 2 & 0.2 \\
\hline Finland & 0 & 0.0 & 8 & 0.1 & 2 & 0.0 & 1 & 0.0 & 2 & 2 & 0.0 \\
\hline France & 39 & 0.1 & 71 & 0.1 & 25 & 0.0 & 36 & 0.1 & 628 & 96 & 0.1 \\
\hline Germany & 70 & 0.1 & 50 & 0.1 & 85 & 0.1 & 80 & 0.1 & 160 & 123 & 0.2 \\
\hline Greece & 24 & 0.2 & 20 & 0.2 & 14 & 0.1 & 24 & 0.2 & 36 & 36 & 0.3 \\
\hline Hungary & 9 & 0.1 & 16 & 0.2 & 9 & 0.1 & 7 & 0.1 & 62 & 31 & 0.3 \\
\hline Iceland & . & . & . & . & . & . & 0 & 0.0 & . & & \\
\hline Ireland & 17 & 0.4 & 16 & 0.4 & 15 & 0.3 & 13 & 0.3 & 23 & 22 & 0.5 \\
\hline Italy & 33 & 0.1 & 43 & 0.1 & 7 & 0.0 & & . & & & \\
\hline Latvia & 2 & 0.1 & 6 & 0.3 & 1 & 0.0 & 1 & 0.0 & 7 & 7 & 0.3 \\
\hline Liechtenstein &. & $\sigma^{\circ}$ & r. & . & & . & & . & & . & \\
\hline Lithuania & 5 & 0.2 & 3 & 0.1 & 20 & 0.7 & 10 & 0.3 & 3 & 3 & 0.1 \\
\hline Luxemburg & 0 & 0.0 & 0 & 0.0 & 1 & 0.2 & 0 & 0.0 & 0 & 0 & 0.0 \\
\hline Malta & 1 & 0.2 & 1 & 0.2 & 3 & 0.7 & 3 & 0.7 & 0 & 0 & 0.0 \\
\hline Netherlands & 30 & 0.2 & 29 & 0.2 & 48 & 0.3 & 26 & 0.2 & 100 & 100 & 0.6 \\
\hline Norway & . & . & . & . & . & . & & . & . & . & \\
\hline Poland & 4 & 0.0 & 3 & 0.0 & 2 & 0.0 & 0 & 0.0 & 43 & 10 & 0.0 \\
\hline Portugal & 29 & 0.3 & 33 & 0.3 & 21 & 0.2 & 37 & 0.4 & 69 & 65 & 0.6 \\
\hline Romania & 181 & 0.9 & 98 & 0.5 & 74 & 0.4 & 65 & 0.3 & 96 & 92 & 0.5 \\
\hline Slovakia & 27 & 0.5 & 7 & 0.1 & 8 & 0.1 & 5 & 0.1 & 12 & 12 & 0.2 \\
\hline Slovenia & 9 & 0.4 & 9 & 0.4 & 4 & 0.2 & 0 & 0.0 & 31 & 31 & 1.5 \\
\hline Spain & 0 & - & 4 & - & 0 & - & 0 & - & 0 & 0 & - \\
\hline Sweden & 4 & 0.0 & 4 & 0.0 & 4 & 0.0 & 5 & 0.1 & 6 & 6 & 0.1 \\
\hline United & 42 & 0.1 & 52 & 0.1 & 78 & 0.1 & 50 & 0.1 & 78 & 78 & 0.1 \\
\hline Kingdom & & & & & & & & & & & \\
\hline EU/EEA & 600 & 0.1 & 545 & 0.1 & 491 & 0.1 & 407 & 0.1 & 1593 & 937 & 0.2 \\
\hline
\end{tabular}


European Centre for Disease Prevention and Control. Annual Epidemiological Report 2016 - Leptospirosis. [Internet]. Stockholm: EDC; 2016. Access Address: http://ecdc.europa.eu/en/healthtopics/leptospirosis/Pages/Annualepidemiological-report-2016.aspx

Leptospirosis prevalence appeared to be high in humans in the cities Samsun, Rize, and İstanbul of Turkey and some other countries (Tables 6,7). In EU countries, leptospirosis prevalence appeared to change according to the years and in Germany in 2014, confirmed cases were high than other EU countries.

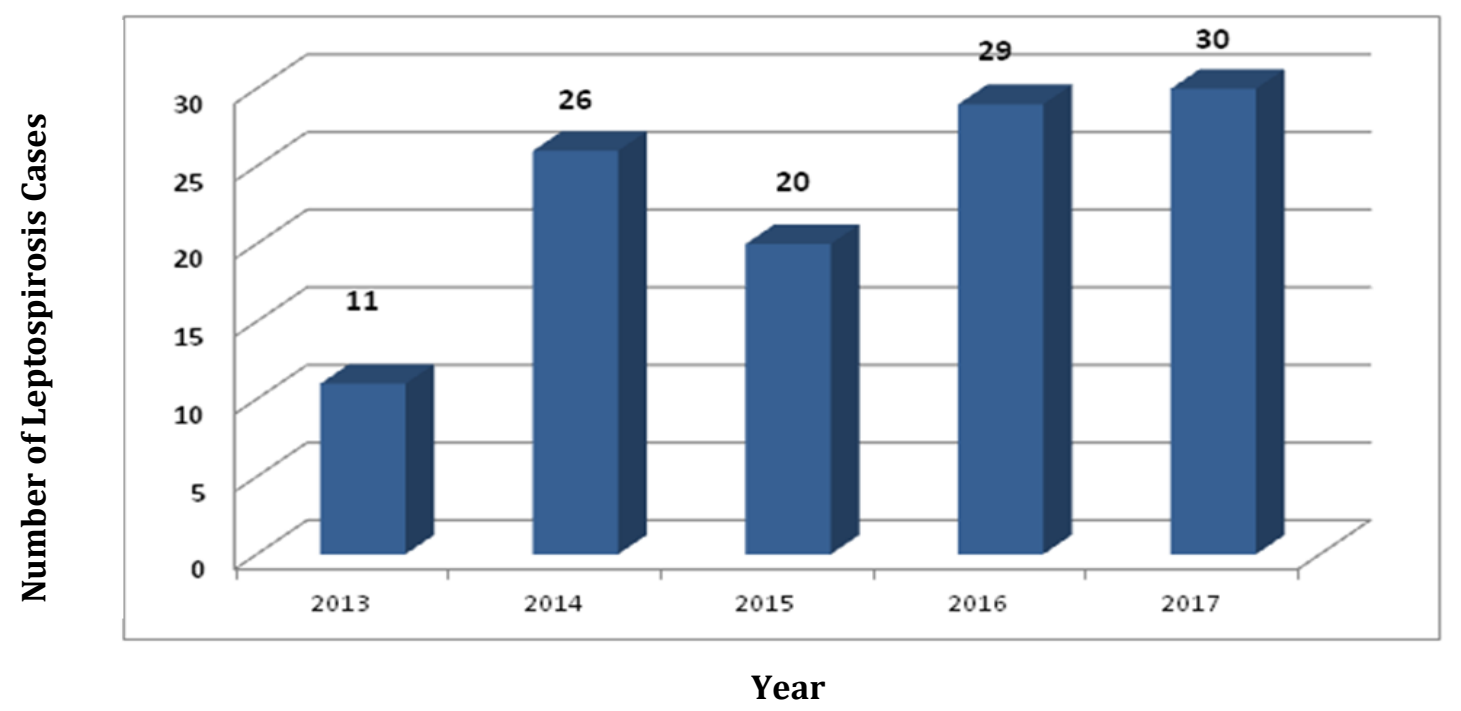

Figure 1 The number of cases due to leptospirosis in humans in 2013-2017 in Turkey (Ministry of Health, 2018) [64].

In Turkey, increasing rate of human cases due to leptospirosis is appeared from 2013 to 2017 in Figure I.

\subsection{Clinical signs of leptospirosis}

Mild symptoms are fever, shivering, muscle pain, nausea, vomiting, cough, and inappetence. Severe symptoms are liver damage, kidney failure, bleeding, hearing loss, dyspnea, vomiting, mental confusion, somnolence, aggressive behavior, seizure, and azotemia [4].

\subsection{Diagnosis of leptospirosis}

Leptospirosis diagnosis is made by culture from blood and urine, and by serological tests ELISA and PCR [4].

\subsection{Treatment of leptospirosis}

In treatment of leptospirosis penicillin G, ampicillin, amoxicillin, doxycycline, and ceftriaxone are used [4]. The intervention method to prevent leptospirosis cases in the high risk groups is the use of chemoprophylaxis. Mostly used antibiotic is doxycycline for chemoprophylaxis of leptospirosis. The efficiency of chemoprophylaxis varies according to when and what amount to administer after exposure to Leptospira spp. [65]. Although antibiotic treatment is applied in six human cases, it is shown by PCR that Leptospira spp. are shed in urine [66]. Leptospira spp. are shown under dark field microscope in a dog 10 days after penicillin and doxycycline treatment [67].

\section{Problems}

- The storage of waste matter and manure near farming.

- The lack of education for farmer.

- Uncontrolled and illegal animal transportation.

- Introducing unquarantined and uncontrolled animals to herd.

- The use of diseased or carrier bulls and stallions for breeding.

- Paying no attention for enough cleanness and disinfection of barns. 
- Not combating rodents [22].

- The contact of children and pregnant women during treatment of animals fed in house [68].

- Feeding raw offal to dogs [24].

- Not to vaccinate animals [69].

- That owners of animals do not apply to the Directorate of Agriculture and Forest for diagnosis of disease when disease occurs and the late removal of the diseased animals from flock.

- Personnel, vehicle and equipment inadequacies on performing planned mass vaccinations.

- The lack of the number of licensed animal market and uncontrolled buying and selling of animals.

- Increased animal movements due to the transportation and in the result of this, becoming difficult that animal movements are controlled.

- Distribution of them to particular area by collecting animals that are not tested with agricultural development cooperative projects.

- That owners of animals don't act conscious enough in the transaction processes; that payments are made from general budget since not having specific budget in combating disease and thus causing time losses.

\section{Solution proposals}

- Animals should be vaccinated with leptospirosis vaccine.

- Requiring laboratory test and certificated animal (animal free of leptospirosis or vaccinated animal against leptospirosis) during new animal selection for herd.

- Milk of the diseased animals should be properly disposed, not be consumed without boiling them or pasteurizing (for $10-15 \mathrm{~min}$ at $70^{\circ} \mathrm{C}$ ).

- The diseased or carrier male animals should not be used for breeding; it should not be forgotten that bulls and stallions transmit the disease agent via mating; requiring laboratory test for bulls and stallions or artificial insemination should be preferred.

- Aborted fetus and placenta should not be handled with bare hands. They should be sent to the laboratory if possible or if not possible, they should be buried by digging a deep hole and liming or burned.

- The disease sources should be determined and eliminated.

- The number of diagnosis laboratory for leptospirosis should be increased.

- Education of researchers and researches on this subject should be promoted.

- Barns and shelters should be paid attention for cleanness and disinfection.

- Raw offal should not be consumed to dogs [24].

- It should be combated with rodents such as mouse, rat, hamster and hedgehog and physical measures should be taken; riversides should be cleaned, and measures should be taken for the prevention of flooding of sewer systems [22].

- In the areas of disease risk, leptospirosis vaccination should be made regularly.

- It should be placed emphasis on the education of breeder.

- Animals should be kept out of contaminated pasture.

- Fly net should be mounted to the windows and doors of barns and pens.

- Vehicle, personnel and equipment deficits should be reinforced for succeeding at mass vaccination.

- Land vehicle including disinfection unit for combating diseases should be provided in Provincial and District of Directorate in order to be more effective for the determination of disease and intervention processes.

- Regular vaccinations against animal diseases should be maintained in a controlled manner for providing all kinds of hygienic conditions.

- Animal wastes should be stored away from shelter.

- Animals suspected with disease should be quarantined for combating disease and the diseased animals should be removed from herd after diagnosed with serological tests.

- Identifying animals and controlling animal movements should be implemented efficiently. Administrative fine should be performed when introducing animal with non-identity card herd.

- In the regions that disease occurs, support payments for livestock farming should be implemented on condition that animals have been vaccinated.

- Illegal animal transportations should be prevented.

- Use of polyvalent vaccines should be noticed and efficiencies of vaccines should be tested.

- In abortion cases, vaccine and antibiotic should be used together.

- Livestock markets should be certified and controlled for animal introduction.

- Children and pregnant women should not contact the diseased animals kept in house [68]. 
- In endemic areas, risky occupational groups such as soldiers, sugar cane and rice workers should be offered with chemoprophylaxis.

- Prophylaxis should be offered to persons going to places with 5\% or higher incidence of leptospirosis.

- Environmental conditions should be restored; contact with contaminated waters should be prevented. (People engaging in water sports should wear protective clothing).

- When skin injury is suspected, treatment should be started.

- Mechanized agriculture should be implemented for preventing disease contamination in agricultural area.

- Proper herbicides should be applied.

\section{Conclusion}

Leptospirosis is a common zoonotic bacterial disease in animals and humans in the world. This disease can be substantially limited with knowing present problems and implementing the preventive measures.

\section{Compliance with ethical standards}

\section{Acknowledgments}

We acknowledge Ministry of Agriculture and Forestry and Ministry of Health giving permission to use leptospirosis data in this study.

\section{Disclosure of conflict of interest}

There is no any conflict to declare by authors in this study.

\section{References}

[1] Sohail ML, Khan MS, Avais M, Zahoor MY, Ijaz M, Ullah A, Fatima Z, Naseer O, Khattak I and Ali S. (2016). Seroprevalence of Leptospira spp. in horses of distinct climatic regions of Punjab, Pakistan. J Equine Vet Sci, 44, 82-89.

[2] Levett PN. (2015). Systematics of Leptospiraceae. Curr Top Microbiol Immunol, 387, 11-20.

[3] Faine S, Adler B, Bolin C and Perolat P. (1999). Leptospira and Leptospirosis, 2nd ed. Melbourne, Australia: MediSci.

[4] Ningal SP, Kothule MB, Jadhav NY, Kadam SD, Katare YS and Hapse SA. (2015). A review of leptospirosis. WJPPS, $4(9), 1531-1543$.

[5] Verma A, Stevenson B and Adler B. (2013). Leptospirosis in horses. Vet Microbiol, 167(1-2), 61-66.

[6] Dupouey J, Faucher B, Edouard S, Richet H, Kodjo A, Drancourt M and Davoust B. (2014). Human leptospirosis: An emerging risk in Europe? Comp Immunol Microbiol Infect Dis, 37(2), 77-83.

[7] Damborg P, Broens EM, Chomel BB, Guenther S, Pasmans F, Wagenaar JA, Weese JS, Wieler LH, Windahl U, Vanrompay D and Guardabassi L. (2016). Bacterial zoonoses transmitted by household pets: state-of-the-art and future perspectives for targeted research and policy actions. J Comp Path, 155 (1 Suppl), S27-S40.

[8] Brockmann S, Piechotowski I, Bock-Hensley O, Winter C, Oehme R, Zimmermann S, Hartelt K, Luge E, Nöckler K, Schneider T, Stark K and Jansen A. (2010). Outbreak of leptospirosis among triathlon participants in Germany, 2006. BMC Infect Dis, 10, 91.

[9] Morgan J, Bornstein SL, Karpati AM, Bruce M, Bolin CA, Austin CC, Woods CW, LingappaJ, Langkop C, Davis B, Graham DR, Proctor M, Ashford DA, Bajani M, Bragg SL, Shutt K, Perkins BA and Tappero JW. (2002). Outbreak of leptospirosis among triathlon participants and community residents in Springfield, Illinois, 1998. Clin Infect Dis, 34(12), 1593-1599.

[10] Goris MGA, Boer KR, Duarte TATE, Kliffen SJ and Hartskeerl RA. (2013). Human leptospirosis trends, the Netherlands, 1925-2008. Emerg Infect Dis, 19(3), 371-378.

[11] Kutsuna S, Kato Y, Koizumi N, Yamamoto K, Fujiya Y, Mawatari M, Takeshita N, Hayakawa K, Kanagawa S and Ohmagari N. (2015). Travel-related leptospirosis in Japan: A report on a series of five imported cases diagnosed at the National Center for Global Health and Medicine. J Infect Chemother, 21(3), 218-223. 
[12] Guerra MA. (2013). Leptospirosis: Public health perspectives. Biologicals, 41(5), 295-297.

[13] Dechet AM, Parsons M, Rambaran M, Mohamed-Rambaran P, Florendo-Cumbermack A, Persaud S, Baboolal S, Ari MD, Shadomy SV, Zaki SR, Paddock CD, Clark TA, Harris L, Lyon D and Mintz ED. (2012). Leptospirosis outbreak following severe flooding: a rapid assessment and mass prophylaxis campaign: Guyana, January-February 2005. PLoS One, 7(7), e39672.

[14] Trevejo RT, Rigau-Perez JG, Ashford DA, McClure EM, Jarguin-Gonzalez C, Amador JJ, de los Reyes JO, Gonzalez A, Zaki SR, Shieh WJ, McLean RG, Nasci RS, Weyant RS, Bolin CA, Bragg SL, Perkins BA and Spiegel RA. (1998). Epidemic leptospirosis associated with pulmonary hemorrhage-Nicaragua, 1995. J Infect Dis, 178(5),1457-1463.

[15] Amilasan AT, Ujiie M, Suzuki M, Salva E, Belo MC, Koizumi N, Yoshimaysu K, Schmidt WP, Marte S, Dimaano EM, Villarama JB and Ariyoshi K. (2012). Outbreak of leptospirosis after flood, the Philippines, 2009. Emerg Infect Dis, 18(1), 91-94.

[16] Chadsuthi S, Modchang C, Lenbury Y, Iamsirithaworn S and Triampo W. (2012). Modeling seasonal leptospirosis transmission and its association with rainfall and temperature in Thailand using time-series and ARIMAX analyses. Asian Pac J Trop Med, 5(7), 539-546.

[17] Desvars A, Cardinale E and Michault A. (2011). Animal leptospirosis in small tropical areas. Epidemiol Infect, 139(2), 167-188.

[18] Sakundarno M, Bertolatti D, Maycock B, Spickett J and Dhaliwal S. (2014). Risk factors for leptospirosis infection in humans and implications for public health intervention in Indonesia and the Asia-Pacific region. Asia Pac J Public Health, 26(1), 15-32.

[19] Mwachui MA, Crump L, Hartskeeri R, Zinsstag J and Hattendorf J. (2015). Environmental and behavioural determinants of leptospirosis transmission: A systematic review. PLoS Negl Trop Dis, 9(9), e0003843.

[20] Himani D, Suman MK and Mane BG. (2013). Epidemiology of leptospirosis: an Indian perspective. J Foodborne Zoonotic Dis, 1(1), 6-13.

[21] Hennebelle JH, Sykes JE and Foley J. (2014). Risk factors associated with leptospirosis in dogs from Northern California: 2001-2010. Vector Borne Zoonotic Dis, 14 (10), 733-739.

[22] Goarant C. (2016). Leptospirosis: risk factors and management challenges in developing countries. Res Rep Trop Med, 7, 49-62.

[23] Bharti AR, Nally JE, Ricaldi JN, Matthias MA, Diaz MM, Lovett MA, Levett PN, Gilman RH, Willig MR, Gotuzzo E and Vinetz JM. (2003). Leptospirosis: a zoonotic disease of global importance. Lancet Infect Dis, 3(12), 757-771.

[24] Sivakumar P and Babu NR. (2014). Implications of leptospirosis in human health - an overview. The North-East Veterinarian, 14(3), 28-30.

[25] Van de Maele I, Claus A, Haesebroukc and Daminet S. (2008). Leptospirosis in dogs: a review with emphasis on clinical aspects. Vet Rec, 163(14), 409-413.

[26] Levett PN. (2001). Leptospirosis. Clin Microbiol Rev, 14(2), 296-326.

[27] Anon (2018a). Data of Ministry of Agriculture and Forestry.

[28] Azkur AK, Kaygusuz S, Aslan ME, Gazyağcı S, Gözütok S and Toyran K. (2013). A survey study on hantavirus, cowpox virus, and Leptospira infections in Microtus hartingi in Kırşehir Province, Central Anatolia, Turkey. Turk J Vet Anim Sci, 37, 434-442.

[29] Aslantaş Ö, Özdemir V, Kiliç S and Babür C. (2005). Seroepidemiology of leptospirosis, toxoplasmosis, and leishmaniosis among dogs in Ankara, Turkey. Vet Parasitol, 129(3-4), 187-191.

[30] Özdemir V and Erol E. (2002). Leptospirosis in Turkey. Vet Rec, 150(8), 248-249.

[31] Gumussoy KS, Ozdemir V, Aydin F, Aslan O, Atabek E, Ica T, O, Duman Z and Ozturk A. (2006). Seroprevalence of bovine leptospirosis in Kayseri, Turkey and detection of leptospires by polymerase chain reaction. J Anim Vet Adv, 8(6), 1222-1229.

[32] Kocabiyık AL and Çetin C. (2004). Bovine leptospirosis in South Marmara region of Turkey: A serological survey. Revue Med Vet, 155(12), 606-608.

[33] Yesilmen S, Arserim NB, Iskk N and Icen H. (2012). Determination of prevalence of pathogenic Leptospira sp. by real-time PCR in cattle in Diyarbakır. YYU Vet Fak Derg, 23(3), 137-139. 
[34] Aslantaş Ö and Özdemir V. (2005). Determination of the seroprevalence of leptospirosis in cattle by MAT and ELISA in Hatay, Turkey. Turk J Vet Anim Sci, 29(4), 1019-1024.

[35] Kenar B and Ozdemir V. (2013). The seroprevalence of leptospirosis in Anatolian buffaloes in Turkey. Revue Med Vet, 164(6), 331-335.

[36] Genç O, Otlu S, Şahin M and Gökçe Hİ. (2005). Seroprevalence of brucellosis and leptospirosis in aborted dairy cows. Turk J Vet Anim Sci, 29(2), 359-366.

[37] Saglam YS, Yener Z, Temur A and Yalcin E. (2008). Immunohistochemical detection of leptospiral antigens in cases of naturally occurring abortions in sheep. Small Rum Res, 74(1-3), 119-122.

[38] Samir A, Soliman R, El-Hariri M, Abdel-Moein K and Hatem ME. (2015). Leptospirosis in animals and human contacts in Egypt: broad range surveillance. Rev Soc Bras Med Trop, 48(3), 272-277.

[39] Lilenbaum W, Ribeiro V, Martin E and Bispo V. (1993). Serological study for detecting anti-leptospira antibodies in Rattus norvegicus from Duque de Caxias, Rio de Janeiro, Brazil. Rev Latinoam Microbiol, 35(4), 357-380.

[40] Heuser E, Fischer S, Ryll R, Mayer-Scholl A, Hoffmann D, Spahr C, Imholt C, Alfa DM, Fröhlich A, Lüschow D, Johne R, Ehlers B, Essbauer S, Nöckler K and Ulrich RG. (2017). Survey for zoonotic pathogens in Norway rat populations from Europe. Pest Manag Sci, 73(2), 341-348.

[41] de Alquerque NF, Martins G, Medeiros L, Lilenbaum W and Ribeiro VMF. (2017). The role of capybaras as carriers of leptospires in periurban and rural areas in the western Amazon. Acta Trop, 169, 57-61.

[42] Vein J, Leblond Belli P, Kodjo A and Berny PJ. (2014). The role of the coypu (Myocastor coypus), an invasive aquatic rodent species, in the epidemiological cycle of leptospirosis: a study in two wetlands in the East of France. Eur J Wildlife Res, 60(1), 125-133.

[43] Mgode GF, Mbugi HA, Mhamphi GG, Ndanga D and Nkwama EL. (2014). Seroprevalence of Leptospira infection in bats roosting in human settlements in Morogoro municipality in Tanzania. Tanzan J Health Res, 16(1), 23-28.

[44] Perez-Flores J, Charruau P, Cedeno-Vazquez R and Atilano D. (2017). Evidence for wild crocodiles as a risk for human leptospirosis, Mexico. EcoHealth, 14(1), 58-68.

[45] Lindtner-Knific R, Vergles-Rataj A, Vlahovic K, Zrimsek P and Dovic A. (2013). Prevalence of antibodies against Leptospira sp. in snakes, lizards and turtles in Slovenia. Acta Vet Scand, 55, 65-69.

[46] Zakeri S, Khorami N, Ganji ZF, Sepahian N, Malmasi AA, Gouya MM and Djadid ND. (2010). Leptospira wolffii, a potential new pathogenic Leptospira species detected in human, sheep and dog. Infect Genet Evol, 10(2), 273277.

[47] Lopez MC, Vila A, Rodon J and Roura X. (2019). Leptospira seroprevalence in owned dogs from Spain. Heliyon, 5(8), e02373.

[48] Abreu JAP, Krawczak FDS, Guedes IB, Souza-Filho AF, Souza GO, Binder LC, de Oliveira CS, Sponchiado J, Melo GL, Labruna MB and Heinemann MB. (2019). Frequency of anti-Leptospira spp. antibodies in dogs and wild small mammals from rural properties and conservation units in southern Brazil. One health, 8, 100104.

[49] Ullmann LS, Hoffmann JL, de Moraes W, Cubas ZS, dos Santos LC, da Silva RC, Moreira N, Guimaraes AM, Camossi LG, Langoni H and Biondo AW. (2012). Serologic survey for Leptospira spp. in captive neotropical felids in Foz do Iguacu, Parana, Brazil. J Zoo Wildl Med, 43(2), 223-228.

[50] Alamuri A, Thirumalesh SRA, Kumari SS, Kumar KV, Roy P and Balamurugan V. (2019). Seroprevalence and distribution of serogroup-specific pathogenic Leptospira antibodies in cattle and buffaloes in the state of Andhra Pradesh, India. Vet World, 12(8), 1212-1217.

[51] Govindan B, Roy P and Chandran DJ. (2015). Prevalence of leptospirosis among buffaloes. Buffalo Bulletin, 34(3), 313-317.

[52] Gamage CD, Koizumi N, Perera AKC, Muto M, Nwafor-Okoli C, Ranasinghe S, Kularatne SA, Rajapakse RP, Kanda K, Lee RB, Obayashi Y, Ohnishi M and Tamashiro H. (2014). Carrier status of leptospirosis among cattle in Sri Lanka: a zoonotic threat to public health. Transbound Emerg Dis, 61(1), 91-96.

[53] Martins G, Penna B, Hamond C, Leite RC-K, Silva A, Ferreira A, Brandao F, Oliveira F and Lilenbaum W. (2012). Leptospirosis as the most frequent infectious disease impairing productivity in small ruminants in Rio de Janeiro, Brazil. Trop Anim Health Prod, 44(4), 773-777. 
[54] Fang F, Collins-Emerson JM, Cullum A, Heuer C, Wilson PR and Benschop J. (2015). Shedding and seroprevalence of pathogenic Leptospira spp. in sheep and cattle at a New Zealand Abattoir. Zoonoses Public Health, 62(4), 258268.

[55] Tadich TA, Tapia C and Gonzalez D. (2016). Seroprevalence of Leptospira spp. in working horses located in the central region of Chile. J Equine Vet Sci, 38, 14-18.

[56] Yllmaz H, Turhan V, Yasar KK, Hatipoglu M, Sunbul M and Leblebicioglu H. (2015). Characteristics of leptospirosis with systemic inflammatory response syndrome: a multicenter study. Ann Clin Microbiol Antimicrobiol, 14, 54.

[57] Turhan V, Polat E, Atasoyu EM, Ozmen N, Kucukardalı Y and Cavuslu S. (2006). Leptospirosis in Istanbul, Turkey: A wide spectrum in clinical course and complications. Scand J Infect Dis, 38(10), 845-852.

[58] Bilir 0. (2016). An old zoonosis coming from Afar: Leptospirosis. Int J Pure Appl Zool, 4(3), 258-261.

[59] van Alphen LB, Kunoe AL, Ceper T, Kahler J, Kjelso C, Ethelberg S and Krogfelt KA. (2015). Trends in human leptospirosis in Denmark, 1980 to 2012. Euro Surveill, 20(4), 21019.

[60] Mohd Ridzuan J, Aziah BD and Zahiruddin WM. (2016). Work environment-related risk factors for leptospirosis among plantation workers in tropical countries: Evidence from Malaysia. Int J Occup Environ Med, 7(3), 156-163.

[61] Padma Kumari J, Sheila Doris T and Usha Krishnan K. (2016). Seroprevalence of leptospirosis in Chennai city, India. Int J Bioassays, 5.3, 4897-4901.

[62] Cook EAJ, de Glanville WA, Thomas LF, Kariuki S, de Clare Bronsvoort BM and Fevre EM. (2017). Risk factors for lesptospirosis seropositivity in slaughterhouse workers in western Kenya. Occup Environ Med, 74, 357-365.

[63] European Centre for Disease Prevention and Control. Annual Epidemiological Report 2016 - Leptospirosis. [Internet]. Stockholm: EDC; 2016.

[64] Anon (2018b). Data of Ministry of Health for leptospirosis cases number in humans in Turkey.

[65] Schneider MC, Velasco-Hernandez J, Min K-D, Leonel DG, Baca-Carrasco D, Gompper ME, Hartskeerl R and MunozZanci C. (2017). The use of chemoprophylaxis after floods to reduce the ocurrence and impact of leptospirosis outbreaks. Int J Environ Res Public Health, 14(6), 594.

[66] Bal AE, Gravekamp C, Hartskeeri RA, De Meza-Brewster J, Korver H and Terpstra WJ. (1994). Detection of leptospires in urine by PCR for early diagnosis of leptospirosis. J Clin Microbiol, 32(8), 1894-1898.

[67] Juvet F, Schuller S, O'Neill EJ, O'Neill PA and Nally JE. (2011). Urinary shedding of spirochaetes in a dog with acute leptospirosis despite treatment. Vet Rec, 168(21), 564.

[68] Azocar-Aedo L, Smits HL and Monti G. (2014). Leptospirosis in dogs and cats: epidemiology, clinical disease, zoonotic implications and prevention. Arch Med Vet, 46(3), 337-348.

[69] Pereira MH, Cooke RF, Alfieri AA and Vasconcelos JL. (2013). Effects of vaccination against reproductive diseases on reproductive performance of lactating dairy cows submitted to AI. Anim Reprod Sci, 137(3-4), 156-162.

\section{How to cite this article}

Bilgili A and Hanedan B. (2019). Importance of leptospirosis for human and animal health, present condition, problems and solution proposals in Turkey and the World. World Journal of Advanced Research and Reviews, 4(2), 49-60. 